\section{Acknowledgments}

I wish to thank Tad Theimer for preparing the illustrations, Rupert Barneby and Ekkehart Malotki for help with the Latin diagnoses, and Patricio Mena and the staff of QCA for logistical support. David Hammond, Randall Scott, Jim Luteyn, Tom Lammers, and one anonymous reviewer kindly offered editorial advice. Field research was supported by NSF grant DEB93-06974 and Northern Arizona University.

\section{Literature Cited}

Ayers, T. J. 1994. Floral resupination in the Lobeliaceae: a twist on a twist. Amer. J. Bot. 81(6, Suppl.): 140 .

Jeppesen, S. 1981. 188. Lobeliaceae. Fl. Ecuador 14: 136-151 [Lysipomia].

McVaugh, R. 1955. A revision of Lysipomia (Campanulaceae, Lobelioideae). Brittonia 8: 69-105.

Simpson, B. B. 1975. Pleistocene changes in the flora of the high tropical Andes. Paleobiology 3: 273-294.

Vuilleumier, F. 1969. Pleistocene speciation in birds living in the high Andes. Nature 223: 1179-1180.

Wimmer, F. E. 1953. Lysipomia. Pages 745-753. In: R. Mansfeld (ed.), Das Pflanzenreich, part 2, Heft 107 (IV. 276b): Campanulaceae-Lobelioideae. II. Akademie-Verlag, Berlin.

\title{
The 1997 Jesse M. Greenman Award
}

The 1997 Jesse M. Greenman Award has been won by Elena Conti for the publication "Circumscription of Myrtales and their relationships to other rosids: Evidence from rbcL sequence data," coauthored by E. Conti, A. Litt, and K. J. Sytsma, and published in American Journal of Botany 83(2): 221-233 (1996). This study is based on a Ph.D. dissertation from the University of Wisconsin under the direction of Dr. Kenneth J. Sytsma.

The Greenman Award, a certificate and a cash prize of $\$ 1000$, is presented each year by the Missouri Botanical Garden. It recognizes the paper judged best in vascular plant or bryophyte systematics based on a doctoral dissertation published during the previous year. Papers published during 1997 are now being accepted for the 30th annual award, which will be presented in the summer of 1998 . Reprints of such papers should be sent to Dr. P. Mick Richardson, Greenman Award Committee, Missouri Botanical Garden, P.O. Box 299, St. Louis, Missouri 63166-0299, U.S.A. In order to be considered for the 1998 award, reprints must be received by 1 June 1998 . 